IJBPAS, December, Special Issue, 2021, 10(12): 01-08

ISSN: $2277-4998$

International Journal of Biology, Pharmacy

and Allied Sciences (IJBPAS)

'A Bridge Between Cabotion and Qandor'

www.jibpas.com

\title{
A STUDY TO ASSESS THE EFFECTIVENESS OF VIDEO ASSISTED TEACHIMG ON HEALTH HAZAROUS OF TOBACCO USE AMONG HIGHER SECONDARY SCHOOL STUDENTS IN VADODARA DISTRICT
}

\section{SURESH V ${ }^{1}$, BHOOMIKA PATEL ${ }^{2}$, BHAVISHA PATEL ${ }^{2}$, AMI CHAVDA $^{3}$, RUPAL CHAUHAN $^{3}$, KEYUR DABHI ${ }^{3}$ AND RAJVIR CHAUHAN ${ }^{3}$}

1: Professor, Department of Mental Health Nursing, Sumandeep Nursing College, Sumandeep Vidhyapeeth an institution Deemed to be University, Pipariya, Vadodara, Gujarat, India

2: Assistant Professor, Department of Mental health Nursing, Sumandeep Nursing College, Sumandeep Vidhyapeeth an institution Deemed to be University, Pipariya, Vadodara,

Gujarat, India

3: B.Sc Nursing, Sumandeep Nursing College, Sumandeep Vidhyapeeth an Institution

Deemed to be University, Pipariya, Vadodara, Gujarat, India

*Corresponding Author: E Mail: Ami Chavda: ami8160chavda@gmail.com

Received $9^{\text {th }}$ May 2021; Revised $10^{\text {th }}$ July 2021; Accepted $2^{\text {th }}$ Aug. 2021; Available online $1^{\text {st }}$ Dec. 2021

https://doi.org/10.31032/IJBPAS/2021/10.12.1001

ABSTRACT

BACKGROUND OF THE STUDY: India is the world's second largest producer of tobacco. Every year about eight lakh to nine lakh Indians die due to tobacco use. Day by day gradually. The consumption of tobacco has increasing among adolescents in India. However, the use of tobacco leads to various major illnesses like cancer and ultimately leads to increase in mortality and morbidity rate. Like other developing countries, the most susceptible time for initiating tobacco use in India is during adolescence and early adulthood, ages 15-24 years. AIM: The main aim of the study is to promote the knowledge regarding health hazardous of tobacco use among adolescent students. MATERIALS AND METHODS: An evaluative research approach with Pre experimental one group (pre-test \& post- test) design was adopted. A Total 195 samples were selected in this study by simple Radom sampling Technique. A Structured questionnaire was used to assess knowledge related to health 
hazards of tobacco use. RESULTS: The results showed that majority of the student in pre-test 143 (73.3\%) had average knowledge 43 (22.1\%) students had good knowledge 9(4.6\%) students had poor knowledge after the post-test majority of students 171(87.7\%) had good knowledge, 24(12.3\%) students had average knowledge and none of the students had poor knowledge. CONCLUSION: The study concluded that, the video assisted teaching programme is significantly effective in enhancing the knowledge level regarding tobacco use among adolescents students.

\section{Keywords: Tobacco, Adolescents, Hazards, Knowledge}

\section{INTRODUCTION}

India is the world's second largest producer of tobacco. Every year about eight lakh to nine lakh. Indians die due to tobacco use [1]. It was estimated in 1999-2001 that five thoudsand five hundred adolescents start using tobacco every day in India, joining the 4 million young people, under the age of 15 , who already use tobacco regularly $[2,3]$. Like other developing countries, the most susceptible time for initiating tobacco use in India is during adolescence and early adulthood, ages 15-24 years [4]. Tobacco is smoked in the forms of beedis and cigarettes or by using devices like hooka, hookli, chhutta, dhumti, or chillum [5, 6, 7]. Tobacco is used in a number of smokeless forms in India, which include betel quid chewing, mishri, khaini, gutka, snuff, and as an ingredient of pan masala. Betel quid is a combination of betel leaf, areca nut, slaked lime, tobacco, catechu and condiments according to individual preferences [8].

\section{HEALTH HAZARDOUS OF TOBACCO}

Smokeless tobacco is associated with many health problems. Using smokeless tobacco: Can lead to nicotine addiction [9]. Is associated with diseases of the mouth [9, 11]. Can increase risks for early delivery and stillbirth when used during pregnancy ${ }^{10}$.Can cause nicotine poisoning in children [12]. May increase the risk for death from heart disease and stroke $[9,11]$ - Using smokeless products can cause serious health problems. Protect your health; don't start. If you do use them, quit. Smokeless tobacco contains nicotine, which is highly addictive $[\mathbf{9}, \mathbf{1 0}]$. Because young people who use smokeless tobacco can become addicted to nicotine, they may be more likely to also become cigarette smokers [18]. Many smokeless tobacco products contain cancer-causing chemicals $[9,14]$. The most harmful chemicals are tobacco-specific nitrosamines, which form during the growing, curing, fermenting, and aging of tobacco. The amount of these chemicals varies by product [9]. The higher the levels of these chemicals, the greater the risk for cancer [11]. Other chemicals found in tobacco can also cause cancer. 
These include [14] a radioactive element (polonium-210) found in tobacco fertilizer. Chemicals formed when tobacco is cured with heat (polynuclear aromatic hydrocarbons - also known as polycyclic

\section{MATERIALS AND METHODS}

The study was conducted in higher secondary school (Shree ambe Vidyalaya) of the Vadodara district to evaluate the effectiveness of video assisting teaching on health hazards of tobacco use. Researcher has been adopted one group pre test post test research design . non probability purposing sampling technique was used to collect the information from the students . a total of 195 students were selected who were studying in Shree ambe Vidyalaya higher secondary school of Vadodara. students knowledge on health hazards of tobacco use has been assessed by using self structured knowledge questionnaires. data was analysed by using descriptive and inferential statistic.

After Conducting inclusion and exclusion Criteria 195 students were selected those who are in higher secondary school in Vadodara. Those who had previous exposure regarding the hazardous of tobacco use. Those who are willing to participate in the study. Students selected from both gender and age limit should be $15-17$ years. Inform constant were taken. After obtaining formal administrative permission from the concerning authorities aromatic hydrocarbons). Harmful metals (arsenic, beryllium, cadmium, chromium, cobalt, lead, Smokeless tobacco causes cancer of the mouth, esophagus, and pancreas [9].

and formal approval from principal of Shree ambe Vidyalaya, Vadodara. The investigator collects the demographic data through online mode from the students. After which data collected in the following three phases; Phase 1: Pre-test conducted to assess existing knowledge regarding health hazards of tobacco use. Phase 2: video assisted teaching regarding health hazards of tobacco use on the same day. Phase 3: After a period of one-week to assess the post-test level of knowledge regarding health hazards of tobacco use among higher secondary school students by using the same questionnaire. In the Descriptive statistics: Frequency and percentage distribution was used to analyse the demographic variables and in the Inferential statistics: Paired t test was used to analyses the effectiveness of video assisted teaching and Chi-square was used to analyses the association between pre-test levels of knowledge regarding health hazards of tobacco use among higher secondary school students with their selected demographic variables. The level of $p<0.05$ was considered as significant. The study concluded that the level of knowledge among higher secondary school 
students regarding health hazards of tobacco use has been improved through effective video assisted teaching program.

\section{RESULTS}

Table 1 shows the following findings: The study of 196 samples reveals that that majority 99(50.2) of them were males and 96(49.2) of the students were females. religion of students shows that majority 178 (91.3\%) students were Hindu, 4 (2.1\%) students were Christian, $11(5.6 \%)$ of them were muslim and $2(1.0 \%)$ belongs to other religion. Education of parents shows that majority 105 (53.8\%) students parents are educated till higher secondary school, $46(20.5 \%)$ were studied up to primary school, $40(20.5 \%)$ were studied up to high school and 4(2.1\%) were not educated. Occupation of parents shows that 79 $(40.5 \%)$ students parents were self employed, 71 (36.4\%) were having their own business, $40 \quad(20.5 \%)$ were professionally occupied and $5(2.6 \%)$ were unemployed. Family income shows that 98 $(50.3 \%)$ parents were having income above Rs.8001/- to $12000 /-$, 23 (11.8\%) were having more than 12000/- , 55 (28.2\%) were having income between Rs.4001/- to 8000/- and 19 (9.7\%) of them having income below Rs.4000/-. Type of family shows that majority $152(77.9 \%)$ were belong to joint family, 39 (20.0\%) belongs to nuclear family, $4(2.1 \%)$ students belongs to extended family. Location of the family shows that majority $168(86.2 \%)$ of them lives in urban area and $26(13.3 \%)$ of the students lives in rural area. Place of staying shows that majority 189 (96.9\%) of them lives at home and $6(3.1 \%)$ of the students lives in hostel. And habits of smoking in family members revealed that majority 179 (91.6\%) were not having any habit of smoking and $16(8.2 \%)$ of them were having habit of smoking.

Table 2 represents that in pre-test $9(4.6 \%)$ students have poor knowledge, 143 (73.3\%) students have average knowledge and only $43(22.1 \%)$ students have good knowledge. In Post-test 24(12.3\%) students have average knowledge, 171(87.7\%) have good knowledge.

Table 3 To test the hypothesis, paired sample " $t$ " test has been used. Data have been analyzed with the use of SPSS version 20.0 and the outputs are depicted in the above table. The table reveals that there is significant improvement between pre-test and post-test score with 0.05 level of significant. " $\mathrm{t}$ " calculated $\left(-18.815^{* * *}\right)$ is greater than the " $\mathrm{t}$ " tabulated (1.98). it suggesting that the video assisted teaching is effective in promoting their knowledge on health hazards of tobacco use . It has been found that there is a significant improvement between knowledge on health hazards of tobacco use with their selected demographic variables. 
Table 4 shows association of the pre-test level of knowledge regarding health hazards of tobacco use among higher secondary school students with selected demographic variable.

*Significant at $0.05 \%$ Level of significant, NS: Non-Significant

Table 4 explained that the demographic variables like Sex $\left(x^{2}=12.592\right)$, Religion $\left(x^{2}=21.062\right)$, education of parents $\left(x^{2}=21.062\right), \quad$ occupation of parents $\left(x^{2}=21.062\right)$, Family income $\left(x^{2}=21.062\right)$, location of the family ( $\left.x^{2}=16.919\right)$, Type of the family ( $\left.x^{2}=16.919\right)$, place of staying ( $\left.x^{2}=12.592\right)$ and Family members habits of smoking $\left(\mathrm{x}^{2}=12.592\right)$ were not associated with pre-test knowledge regarding health hazards of tobacco use. The above table showed that, there was no significant association between level of knowledge of higher secondary school students and demographic variables in pre-test score.

Table 1: Frequency distribution of selective demographic characteristics $(\mathrm{N}=195)$

\begin{tabular}{|c|c|c|c|c|}
\hline SR. NO & CHARACTERISTICS & CATEGORIES & FREQUENCY & PERCENTAGE \\
\hline \multirow[t]{2}{*}{1} & \multirow[t]{2}{*}{ Sex } & 1. $\quad$ Male & 99 & $50.8 \%$ \\
\hline & & 2. $\quad$ Female & 96 & $49.2 \%$ \\
\hline \multirow[t]{4}{*}{2} & \multirow[t]{4}{*}{ Religion } & 1. Hindu & 178 & $91.3 \%$ \\
\hline & & 2. $\quad$ Christian & 4 & $2.1 \%$ \\
\hline & & 3. Muslim & 11 & $5.6 \%$ \\
\hline & & 4. Others & 2 & $1.0 \%$ \\
\hline \multirow[t]{5}{*}{3} & \multirow[t]{5}{*}{ Education of parents } & $\begin{array}{ll}\text { 1. } & \text { No formal } \\
\text { education }\end{array}$ & 4 & $2.1 \%$ \\
\hline & & 2. Primary school & 46 & $23.6 \%$ \\
\hline & & 3. High school & 40 & $20.5 \%$ \\
\hline & & $\begin{array}{c}\text { 4. Higher secondary } \\
\text { school }\end{array}$ & 105 & $53.8 \%$ \\
\hline & & 5. $\quad$ Post graduate & $\mathbf{0}$ & $0.00 \%$ \\
\hline \multirow[t]{4}{*}{4} & \multirow[t]{4}{*}{ Occupation of parents } & 1. Unemployed & 5 & $2.6 \%$ \\
\hline & & 2. Professional & 40 & $20.5 \%$ \\
\hline & & 3. Business & 71 & $36.4 \%$ \\
\hline & & 4. Self employ & 79 & $40.5 \%$ \\
\hline \multirow[t]{4}{*}{5} & \multirow[t]{4}{*}{ Family income } & 1. $\quad$ Below RS.4000/- & 19 & $9.7 \%$ \\
\hline & & 2. $\quad$ RS 4001-8000/- & 55 & $28.2 \%$ \\
\hline & & $\begin{array}{c}\text { 3. } \\
\text { Above Rs.8001- } \\
12000 /-\end{array}$ & 98 & $50.3 \%$ \\
\hline & & 4. Above Rs.12001/- & 23 & $11.8 \%$ \\
\hline \multirow[t]{3}{*}{6} & \multirow[t]{3}{*}{ Type of family } & 1. Joint family & 152 & $77.9 \%$ \\
\hline & & 2. Nuclear family & 39 & $20.0 \%$ \\
\hline & & 3. Extended family & 4 & $2.1 \%$ \\
\hline \multirow[t]{2}{*}{7} & \multirow[t]{2}{*}{ Location of the family } & 1. Urban area & 168 & $86.2 \%$ \\
\hline & & 2. $\quad$ Rural area & 26 & $13.3 \%$ \\
\hline \multirow[t]{2}{*}{8} & \multirow[t]{2}{*}{ Place of staying } & 1. Home & 189 & $96.9 \%$ \\
\hline & & 2. $\quad$ Hostel & 6 & $3.1 \%$ \\
\hline \multirow[t]{2}{*}{9} & \multirow{2}{*}{$\begin{array}{c}\text { Family members habits of } \\
\text { smoking }\end{array}$} & 1. Yes & 16 & $8.2 \%$ \\
\hline & & 2. No & 179 & $91.6 \%$ \\
\hline
\end{tabular}

Table 2: Differences of frequency and percentage between pre test and post test

\begin{tabular}{|c|c|c|c|c|c|}
\hline \multirow{2}{*}{ Sr. no. } & \multirow{2}{*}{ Knowledge level } & \multicolumn{2}{|c|}{ Pre test } & \multicolumn{2}{c|}{ Post test } \\
\cline { 3 - 6 } & & Frequency & Percentage & Frequency & Percentage \\
\hline 1 & Poor & 9 & 4.6 & - & - \\
\hline 2 & Average & 143 & 73.3 & 24 & 12.3 \\
\hline 3 & Good & 43 & 22.1 & 171 & 87.7 \\
\hline
\end{tabular}


Table 3: Significance of the difference between pre and post-test knowledge score

\begin{tabular}{|c|c|c|c|c|c|c|}
\hline $\begin{array}{c}\text { Over all } \\
\text { Knowledge level }\end{array}$ & Mean & Mean difference & Standard deviation & $\mathbf{t}$ & df & Paired 't' value \\
\hline PRE TEST & $\mathbf{2 . 1 7 4 4}$ & \multirow{2}{*}{$\mathbf{0 . 7 0 2 5}$} & $\mathbf{. 4 8 7 3 2}$ & $\mathbf{- 1 8 . 8 1 5}$ & 194 & $\begin{array}{c}1.98 \\
\text { Significance }\end{array}$ \\
\cline { 1 - 2 } $\begin{array}{c}\text { POST } \\
\text { TEST }\end{array}$ & $\mathbf{2 . 8 7 6 9}$ & & .32937 & & & \\
\hline
\end{tabular}

Table 4: Association between level of knowledge in pre test with demographic variables

\begin{tabular}{|c|c|c|c|c|c|}
\hline \multirow[t]{2}{*}{ Characteristics } & \multirow[t]{2}{*}{ Frequency } & \multicolumn{3}{|c|}{ Level of knowledge } & \multirow[t]{2}{*}{ Significance } \\
\hline & & Poor & Average & Good & \\
\hline \multicolumn{6}{|l|}{ 1. Sex } \\
\hline a) Male & 99 & 4 & 72 & 23 & \multirow{2}{*}{$\begin{array}{c}1.96 \\
D f=6 \\
P=12.592 \\
\text { NS }\end{array}$} \\
\hline b) Female & 96 & 5 & 71 & 20 & \\
\hline \multicolumn{6}{|l|}{ 2. $\quad$ Religion } \\
\hline a) Hindu & 178 & 8 & 128 & 42 & \multirow{3}{*}{$\begin{array}{c}2.02 \\
D f=12 \\
P=21.062 \\
\text { NS }\end{array}$} \\
\hline b) Christian & 4 & $\mathbf{0}$ & 4 & $\mathbf{0}$ & \\
\hline c) Muslim & 11 & 1 & 10 & $\mathbf{0}$ & \\
\hline d) Others & 2 & $\mathbf{0}$ & 1 & 1 & \\
\hline \multicolumn{6}{|l|}{ 3. Education of Parents } \\
\hline a) No formal education & 4 & $\mathbf{0}$ & 2 & 2 & \multirow{5}{*}{$\begin{array}{c}1.99 \\
D f=12 \\
21.026 \\
\text { NS }\end{array}$} \\
\hline b) Primary school & 46 & 3 & 33 & 10 & \\
\hline c) High school & 40 & 1 & 32 & 7 & \\
\hline d) Higher secondary school & 105 & 5 & 76 & 24 & \\
\hline e) Post graduate & $\mathbf{0}$ & $\mathbf{0}$ & $\mathbf{0}$ & $\mathbf{0}$ & \\
\hline \multicolumn{6}{|l|}{$\begin{array}{c}\text { Occupation of the } \\
\text { parents }\end{array}$} \\
\hline a) Unemployed & 5 & $\mathbf{0}$ & 3 & 2 & \multirow{4}{*}{$\begin{array}{c}2.014 \\
D f=12 \\
P=21.026 \\
\text { NS }\end{array}$} \\
\hline b) Professional & 40 & 1 & 34 & 5 & \\
\hline c) Business & 71 & 5 & 49 & 17 & \\
\hline d) Self employ & 79 & 3 & 57 & 19 & \\
\hline \multicolumn{6}{|l|}{ 5. Family income } \\
\hline a) Below Rs.4000/- & 19 & $\mathbf{0}$ & 14 & 5 & \multirow{4}{*}{$\begin{array}{c}2.02 \\
D f=12 \\
P=21.026 \\
\text { NS }\end{array}$} \\
\hline b) Rs.4001- Rs.8000/- & 55 & 2 & 42 & 11 & \\
\hline $\begin{array}{c}\text { c) Above Rs.8001- } \\
\text { Rs.12000/- }\end{array}$ & 98 & 6 & 74 & 18 & \\
\hline d) Above Rs.12000/- & 23 & 1 & 13 & 9 & \\
\hline \multicolumn{6}{|l|}{ 6. Type of family } \\
\hline a) Joint family & 152 & 8 & 108 & 36 & \multirow{4}{*}{$\begin{array}{c}1.988 \\
D f=9 \\
P=16.919 \\
\text { NS }\end{array}$} \\
\hline b) Nuclear family & 39 & 1 & 31 & 7 & \\
\hline c) Extended family & 4 & $\mathbf{0}$ & 4 & $\mathbf{0}$ & \\
\hline \multicolumn{5}{|l|}{ 7. Location of the family } & \\
\hline a) Urban area & 168 & 8 & 125 & 35 & \multirow{2}{*}{$\begin{array}{c}1.977 \\
D f=9 \\
P=16.919 \\
\text { NS }\end{array}$} \\
\hline b) Rural area & 26 & 1 & 17 & 8 & \\
\hline \multicolumn{6}{|l|}{ 8. $\quad$ Place of staying } \\
\hline a) Home & 189 & 9 & 139 & 41 & \multirow{2}{*}{$\begin{array}{c}1.96 \\
D f=6 \\
P=12.592 \\
\text { NS }\end{array}$} \\
\hline b) Hostel & 6 & $\mathbf{0}$ & 4 & 2 & \\
\hline \multicolumn{6}{|l|}{$\begin{array}{cc}\text { 9. Family members habits } \\
\text { of smoking }\end{array}$} \\
\hline a) Yes & 16 & 1 & 10 & 5 & \multirow{2}{*}{$\begin{array}{c}1.97 \\
D f=6 \\
P=12.592 \\
\text { NS }\end{array}$} \\
\hline b) No & 179 & 8 & 133 & 38 & \\
\hline
\end{tabular}




\section{DISCUSSION}

The study was undertaken to determine the effectiveness of video teaching on level of knowledge regarding health hazards of tobacco use among adolescence in Shree Ambe Vidyalaya at Vadodara district.

One group pre test post test design was adopted for the study. The results and discussion of the study was based on the findings obtained from the statistical analysis.

The findings shown that the mean value of adolescence was 2.17 and the standard deviation was 0.48 Out of 195 students none of them had adequate knowledge regarding health hazards of tobacco use and the remaining 43(22.1\%) had good knowledge regarding health hazards of tobacco use and the remaining $143(73.3 \%)$ had average knowledge and 9 (4.6\%) had poor knowledge.

The finding shown that the mean value of adolescence was 2.87 and the standard deviation was 0.329 . Out of 195 students $171(87.7 \%)$ good knowledge regarding health hazards of tobacco use and the remaining $24 \quad(17.3 \%)$ had average knowledge regarding health hazards of tobacco use and none of them poor. The result of the test score indicates that video teaching was effective to the adolescence regarding health hazards of tobacco use.

The findings shown that the Pre-test mean value (2.17) and post test mean value (2.87) and pre test and post test standard deviation were 0.487 and 0.329 . The t-test $(-18.815)$ and table value (2) respectively. The calculated value is more than the table value. Hence, it is found to be more effective.

\section{CONCLUSION}

The study concluded that, the video assisted teaching programme is significantly effective in enhancing the knowledge level regarding tobacco use among adolescents students.

\section{CONSENT}

As per international standard or university standard, student's written consent has been obtained.

\section{ETHICAL APPROVAL}

Ethical approval was obtained prior to the conduction of study. The study was approved from ethical committee of Sumandeep Vidhyapeeth an institutional ethical committee and ethical approval number is SVIEC/ON/NURS/SRP/21033

\section{COMPETING INTERESTS}

Authors have declared that no competing interests exits.

\section{REFERENCES}

[1] Jha P, Chaloupka FJ. (eds.) Curbing the Epidemic: Governments and the Economics of Tobacco Control. Washington DC: The World Bank, 1999.

[2] Warren CW, Riley L, Asma S, Eriksen MP, Green L, Blanton C, 
Loo C, Batchelor S, Yach D.

Tobacco use in youth: a surveillance report from the Global Youth Tobacco Survey Project. Bulletin of World Health Organization 2000; 78: 868-876.

[3] Heishman SJ. Tobacco - the once and future addiction: editorial. Addiction 2001; 96: 1389-1390.

[4] Patel DR. Smoking and children. Indian Journal of Pediatrics 1999; 66: 817-24.

[5] Singhi S, Broca JS, Mathur GM. Smoking behaviour of rural schoolboys. Indian Pediatrics 1987; 24: 655-659.

[6] Reddy KS, Gupta PC (eds). Report on Tobacco Control in India. Ministry of Health and Family Welfare, New Delhi, Government of India, 2004.

[7] Patel DR. Smoking and Children. Indian J Pediatr. 1999; 66: 817-824.

[8] Rudman A. India Inhales, 2000. Available from URL: http://www.unaff.org/2001/findia.html. Accessed on 7-06-05.

[9] National Sample Survey Organization (NSS). A note on consumption of tobacco in India, NSS 50th round (1993-1994).
Sarvekshana: A Journal of the National Sample Survey Organization 1998; 21: 69-100.

[10] Gupta PC. Survey of sociodemographic characteristics of tobacco use among 99598 individuals in Bombay, India using handheld computers. Tobacco Control 1996; 5: 114120.

[11] Gupta PC, Sinor PN, Bhonsle RB, Pawar VS, Mehta HC. Oral submucous fibrosis in India: a new epidemic? The National Medical Journal of India 1998; 11: 113116.

[12] Bhonsle RB, Murti PR, Gupta PC, Mehta FS. Reverse dhumti smoking in Goa: an epidemiological study of 5449 villagers for oral precarious lesions. The Indian Journal of Cancer 1976; 13: 301-305.

[13] Sinha DN, Gupta PC. Tobacco and areca nut use in male medical students of Patna. National Medical Journal of India 2001; 14: 176-178.

[14] Gupta PC. Gutka: a major new tobacco hazard in India. Tobacco Control 1999; 8: 132. 